\title{
Novel Combination of Bioleaching and Persulfate for the Removal of Heavy Metals from Metallurgical Industry Sludge
}

\section{Chen Chen}

Inner Mongolia University of Technology

Huidong Li ( $\square$ lihuidong@imut.edu.cn )

Inner Mongolia University of Technology https://orcid.org/0000-0002-6629-4692

Fengjiao Cui

Inner Mongolia University of Technology

Zhixia Wang

Inner Mongolia University of Technology

Xinxin Liu

Inner Mongolia University of Technology

\section{Gang Jiang}

Inner Mongolia University of Technology

\section{Tianjia Cheng}

Inner Mongolia University of Technology

\section{Runying Bai}

Inner Mongolia University of Technology

\section{Lei Song}

Inner Mongolia University of Technology

\section{Research Article}

Keywords: Bioleaching, Persulfate, Removal, Iron-oxidizing bacteria, Heavy metals, Metallurgical industry sludge

Posted Date: August 19th, 2021

DOI: https://doi.org/10.21203/rs.3.rs-616023/v1

License: (c) (i) This work is licensed under a Creative Commons Attribution 4.0 International License.

Read Full License 
Version of Record: A version of this preprint was published at Environmental Science and Pollution Research on January 14th, 2022. See the published version at https://doi.org/10.1007/s11356-02118068-z. 

removal of heavy metals from metallurgical industry sludge

Chen Chen, Huidong Li*, Fengjiao Cui, Zhixia Wang, Xinxin Liu, Gang Jiang, Tianjia Cheng,

4 Runying Bai, Lei Song

School of Civil Engineering, Inner Mongolia University of Technology, Hohhot 010051, PR China

\section{Abstract}

The objective of this study was to remove heavy metals from the metallurgical industry sludge by bioleaching alone and bioleaching combined with persulfate (PDS). The results showed that the removal of $\mathrm{Cu}, \mathrm{Zn}, \mathrm{Pb}$ and $\mathrm{Mn}$ reached to $70 \%, 83.8 \%, 25.2 \%$ and $76.9 \%$ by bioleaching alone after 18 d, respectively. The experiment of bioleaching combined with PDS was carried out in which the optimal additive dosage of $\mathrm{K}_{2} \mathrm{~S}_{2} \mathrm{O}_{8}, 8 \mathrm{~g} / \mathrm{L}$, was added to bioleaching after $6 \mathrm{~d}$. After $1 \mathrm{~h}$, the removal of 4 heavy metals reached 75.1, 84.3, 36.7 and $81.6 \%$, respectively. Compared with bioleaching alone, although the increase in removal efficiency was not obvious, the treatment cycle was distinctly shortened from $18 \mathrm{~d}$ to $6 \mathrm{~d}+1 \mathrm{~h}$. Scanning electron microscopy (SEM) results showed that the surface morphology of the sludge was changed significantly by the combined treatment. The content of heavy metals was significantly reduced after bioleaching combined with PDS by energy dispersive X-ray spectroscopy (EDX). The treated sludge mainly existed in a stable form, and the bioavailability was reduced with European Community Bureau of Reference (BCR) morphology analysis. Therefore, this study proved that the combination of bioleaching and PDS was an efficient method to remove heavy metals from metallurgical industry sludge.

\section{Keywords}

Bioleaching; Persulfate; Removal; Iron-oxidizing bacteria; Heavy metals; Metallurgical industry sludge

\section{Introduction}

With the rapid development of the metallurgical industry, a large amount of metallurgical industry sludge has been produced. The composition of industrial sludge is complex because of the variety of sources, mainly heavy metals, organic pollutants, viruses and microorganisms (Liu et al. 2020b; Lu et al. 2019; Romdhana et al. 2009). At present, the above substances contained in industrial sludge are not

\footnotetext{
* Corresponding author: Tel.: +86 15947032253.

E-mail address: lihuidong@imut.edu.cn (HD. Li).
} 
environmentally friendly and dangerous, but landfills are still the most important method of disposal of industrial sludge (Gunarathne et al. 2019). If untreated sludge is buried directly, it may cause serious problems. Toxic metals enter the soil and groundwater due to environmental changes or infiltration, and then they will be absorbed and utilized by animals and plants through the food chain, which will be harmful to human health and the ecological environment (Mulligan et al. 2001; Nzihou \&Stanmore 2013). In addition, it is also very important to recycle the rich heavy metals in the sludge and avoid waste of resources. Therefore, in consideration of environmental protection and resource recovery, it is imminent to find a solution to the above problems.

Bioleaching methods are widely considered due to their low cost and energy consumption, simple operation, high efficiency of treatment and environmental friendliness, and are considered to be the most promising method (Naseri et al. 2019). Bioleaching technology involves dissolving heavy metals through direct and indirect action of acidophilic bacteria, and then removing heavy metals through dehydration (Bayat \&Sari 2010). The microorganisms commonly used for bioleaching are mainly sulfur or iron oxidizing bacteria, such as At. thiooxidans and At. Ferrooxidans (A.F), being the most commonly used (Yang et al. 2020). Aspergillus niger and Leptospirillum ferriphilum have also been reported for bioleaching (Nikfar et al. 2020). However, existing studies have shown that mixed bacteria can dissolve heavy metals better than purely cultured bacteria, due to the synergistic effect of acidophilic microorganisms (Xin et al. 2009). Although many researchers have adopted biological leaching to remove heavy metals in sludge, the long operating cycle limits its practical application. Therefore, it is necessary to shorten the operating cycle and improve the processing efficiency for practical applications.

PDS is increasingly being researched in advanced oxidation technology. It is mainly used to treat difficult-to-degrade organic pollutants with sulfate radicals in sludge and wastewater, and it has also been reported to be used for sludge dewatering (Guo et al. 2021; Liu et al. 2020a; Zhou et al. 2021). It has the advantages of low cost, environmental friendliness, and strong oxidation ability. There are relatively few research reports on the use of persulfate to remove heavy metals from sludge (Huang et al. 2019). Existing studies have shown that the lower the $\mathrm{pH}$ is, the higher the dissolution rate of metals under the optimal conditions of PDS (Yuan et al. 2020). In addition, the presence of $\mathrm{Fe}^{2+}$ can catalyse the generation of $\mathrm{SO}_{4}^{2-}$. derived from PDS. The existence of sulfate radicals will accelerate the degradation of sludge EPS and organic matter, and then promote the dissolution of heavy metals (Li et 
al. 2021).

In this study, the method of bioleaching combined with PDS was used to remove heavy metals from metallurgical industrial sludge. The main experimental contents involve the removal efficiency of heavy metals, the treatment cycle and the transformation of heavy metal forms by bioleaching and combined bioleaching with PDS. In the following sections, the combined treatment with persulfate after biological leaching is called the combined treatment.

\section{Materials and methods}

\subsection{Sludge samples and chemicals}

The sludge used in this experiment was taken from a metallurgical industrial sludge dewatering workshop in Baotou City, China. The collected sludge was passed through a $75 \mu \mathrm{m}$ sieve, and then stored at $4{ }^{\circ} \mathrm{C}$ before utilization. The sludge sample was dried at $105^{\circ} \mathrm{C}$ for $2 \mathrm{~h}$ to constant weight, and the sludge solid content was calculated using the differential weight method after the water evaporated. The $\mathrm{pH}$ and oxidation-reduction potential (ORP) of the sludge were measured with an integrated measuring instrument (HI 8424, HANNA, Italy). After drying, the sludge was crushed into powder and passed through a $0.75 \mu \mathrm{m}$ sieve. Powder $(1.00 \mathrm{~g})$ was digested by the NHO3-HF-HClO4 method. The content of each metal in the leaching solution was detected with atomic absorption spectrometry (AA-6880, SHIMADZU, Japan). The main characteristics of raw sludge were measured as follows: solid content, $18.64 \%$, the total metal contents (on a dry weight base) in the sludge were 161.1, 2684.3, 1151.3 and $401.5 \mathrm{mg} / \mathrm{kg}$ for $\mathrm{Cu}, \mathrm{Zn}, \mathrm{Pb}$ and $\mathrm{Mn}$, respectively. The solid content was adjusted to $2 \%$ using deionized water, and the $\mathrm{pH}$ and $\mathrm{ORP}$ were 7.08 and $86 \mathrm{mV}$, respectively.

\subsection{Culture of the iron-oxidizing bacteria}

Fresh sludge was collected from the sewage treatment plant, as the seed sludge to enrich and culture iron-oxidizing bacteria. The microorganism enrichment culture procedure was as follows. Initially, $300 \mathrm{~mL}$ seed sludge at a $2 \%$ solid content was added into a $500 \mathrm{~mL}$ Erlenmeyer flask with 20 $\mathrm{g} / \mathrm{L} \mathrm{FeSO} \mathrm{F}_{4} \cdot 7 \mathrm{H}_{2} \mathrm{O}$ as the iron substrate. Then the flask was agitated in an orbital shaker at shaking speeds of $150 \mathrm{r} / \mathrm{min}$ and $30^{\circ} \mathrm{C}$ until the $\mathrm{pH}$ of the seed sludge dropped to less than 2.0. It can be considered that the primary enrichment culture has ended. Subsequently, a sample of fresh sludge was inoculated with $10 \%(\mathrm{v} / \mathrm{v})$ of the enriched sludge and supplemented with $20 \mathrm{~g} / \mathrm{L} \mathrm{FeSO}_{4} \cdot 7 \mathrm{H}_{2} \mathrm{O}$. Under the same conditions, iron-oxidizing bacteria were enriched and cultured twice. After three cycles of enrichment culture, A.F were greatly enriched in the acidified sludge, Therefore, A.F can be used as an 
inoculum for bioleaching. The $\mathrm{pH}$ value and ORP value of the sludge were measured every $24 \mathrm{~h}$. Before the measurement, the weight of the conical flask was weighed, and the evaporated water was supplemented with deionized water.

\subsection{Bioleaching experiments}

The bioleaching experiments were conducted with $700 \mathrm{~mL}$ of sludge using $5 \%(\mathrm{v} / \mathrm{v})$ inoculum and $10 \mathrm{~g} / \mathrm{L}(\mathrm{w} / \mathrm{v}) \mathrm{FeSO}_{4} \cdot 7 \mathrm{H}_{2} \mathrm{O}$ at $30{ }^{\circ} \mathrm{C}$ and $150 \mathrm{r} / \mathrm{min}$ in $1000 \mathrm{~mL}$ flasks. Sludge acidification will result from inoculation of microorganisms and the addition of $\mathrm{FeSO}_{4} \cdot 7 \mathrm{H}_{2} \mathrm{O}$. The contents of heavy metal, $\mathrm{pH}$ and ORP were determined after bioleaching for 1-6 d and 6-18 d, in which the samples were measured every day in the first stage, and every two days in the second stage. The evaporated water was supplemented with deionized water by the weighing difference method every day. The control experiments were conducted similarly without using inoculum and ferrous sulfate. Three sets of parallel experiments were set up, and the different measured values between repeated samples were indicated by the error bars in the corresponding graphs.

\subsection{Bioleaching combined with PDS experiments}

When the $\mathrm{pH}$ dropped to approximately 2.5 for the bioleaching experiments, PDS was added. The optimization experiments of PDS dosage were set to $0,2,4,6,8,10$ and $12 \mathrm{mg} / \mathrm{L}$. The combination experiments between bioleaching and PDS were completed at $30{ }^{\circ} \mathrm{C}$ and $150 \mathrm{r} / \mathrm{min}$. The contents of heavy metals were measured when PDS was added for $1 \mathrm{~h}$. The different measurement deviations between sample duplicates are expressed with error bars in the corresponding figures. After adding PDS, the reaction was carried out for $1 \mathrm{~h}$ under the original conditions.

\subsection{Analysis}

Samples were collected from the flasks every day for $\mathrm{pH}$ and ORP determination, and after centrifugation at $3000 \mathrm{~g}$ for $20 \mathrm{~min}$, the concentration of each heavy metal was determined using an atomic absorption spectrophotometer after filtering with $0.45 \mu \mathrm{m}$. The speciation distributions of heavy metals in the samples were analysed according to the three-step extraction procedure from the BCR (Quevauviller et al. 1997).

To describe the changes in the chemical structure of the sludge, Fourier Transform Infrared Spectrometer (FTIR, Nicolet, USA) was used to characterize the sludge before and after treatment. SEM (Sigma, Germany) was used to analyse the changes in sludge surface morphology and structure before and after bioleaching. The distribution of elements in the sludge before and after treatment was 
observed by energy dispersive X-ray spectroscopy (EDX, SHIMADZU, Japan).

119

\section{Results and discussion}

\subsection{Heavy metal speciations in sludge}

The impact of heavy metals in sludge on bioavailability and the ecological environment not only on the sludge concentration, but also on the chemical forms (Chen et al. 2008). The chemical forms of heavy metals affect the migration, bioavailability and ecotoxicity of heavy metals (Fuentes et al. 2004; Renoux et al. 2001). According to the BCR method, the speciation of heavy metals can be divided into four categories: exchangeable fraction (B1), reducing fraction (B2), oxidizable fraction (B3), and residual fraction (B4) (Quevauviller et al. 1997). It is believed that B1 and B2 can be adsorbed on the surface of particles, and can also be bound to carbonates and Fe-Mn hydroxides. When the environment changes, migration easily occurs for the heavy metals B1 and B2, which are considered bioavailable fractions. B3 usually binds to sulfides or organics. B4 remains in the crystal structure, which prevents its easy release under natural conditions. Hence, B4 is taken as a stable state (Deng et al. 2013).

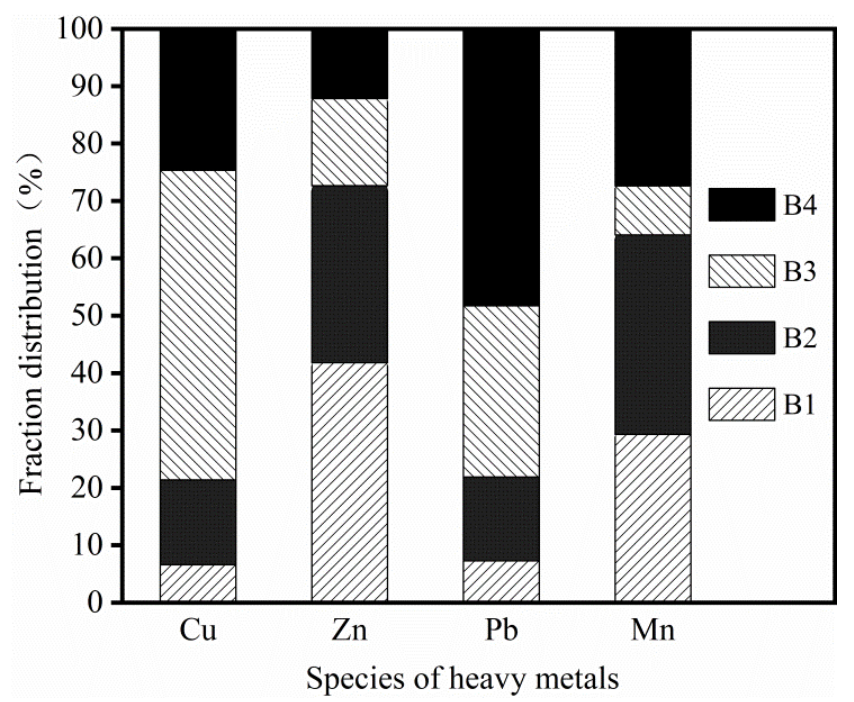

Fig. 1 Heavy metal fraction in raw sludge

As shown in Fig. 1, the majority of $\mathrm{Cu}$ and $\mathrm{Pb}$ existed in the stable forms of $\mathrm{B} 3$ and $\mathrm{B} 4$, as high as $78.6 \%$ and $78.1 \%$, respectively. The above results indicated that the toxicities of $\mathrm{Cu}$ and $\mathrm{Pb}$ were relatively low and did not easily migrate under natural conditions (Liu et al. 2008). $\mathrm{Zn}$ was the most unstable heavy metal, $72.7 \%$ of which existed in the form of B1 and B2. More than half of Mn also existed in an unstable state. Therefore, $\mathrm{Zn}$ and $\mathrm{Mn}$ were sensitive to the environment and tended to migrate.

\subsection{Evolution of pH and ORP during bioleaching}



group and the control group. The changes in $\mathrm{pH}$ and ORP reflect the degree of bioleaching and the growth of iron-oxidizing bacteria (Chartier \&Couillard 1997). The $\mathrm{pH}$ of the experimental group sharply decreased from 7.08 to 4.64 after the $1 \mathrm{~d}$ bioleaching experiment, which may be caused by the inoculation of iron-oxidizing bacteria. The $\mathrm{pH}$ decreased continuously to 2.37 and remained relatively stable until the sixth day. In contrary, the ORP of sludge increased rapidly from $86 \mathrm{mV}$ to $580 \mathrm{mV}$ within $6 \mathrm{~d}$, then slightly increased to the 18th day, and finally remained at $621 \mathrm{mV}$. In the control group, the $\mathrm{pH}$ barely changed within $18 \mathrm{~d}$. It increased slightly from the first day to the 5 th day, then began to decline, and finally stabilized at approximately 6.85 . This slight change may be due to uninoculated microorganisms and energy substances, thus demonstrating the absence of acidophilic iron-oxidizing bacteria in the control group (Fontmorin \&Sillanpää 2015). Similarly, the change in ORP in the control group was slight, increasing only from $86 \mathrm{mV}$ to $120 \mathrm{mV}$. The increase in ORP in the experimental group can be attributed to sulfuric acid and $\mathrm{Fe}^{3+}$ by sulfur-oxidizing bacteria (Wen et al. 2013). When the $\mathrm{pH}$ drops to 2.0 , it remains stable because the $\mathrm{pH}$ of the bioleaching system has fallen to the optimum pH of acidophilus and the energy material has been consumed (Shi et al. 2015a).
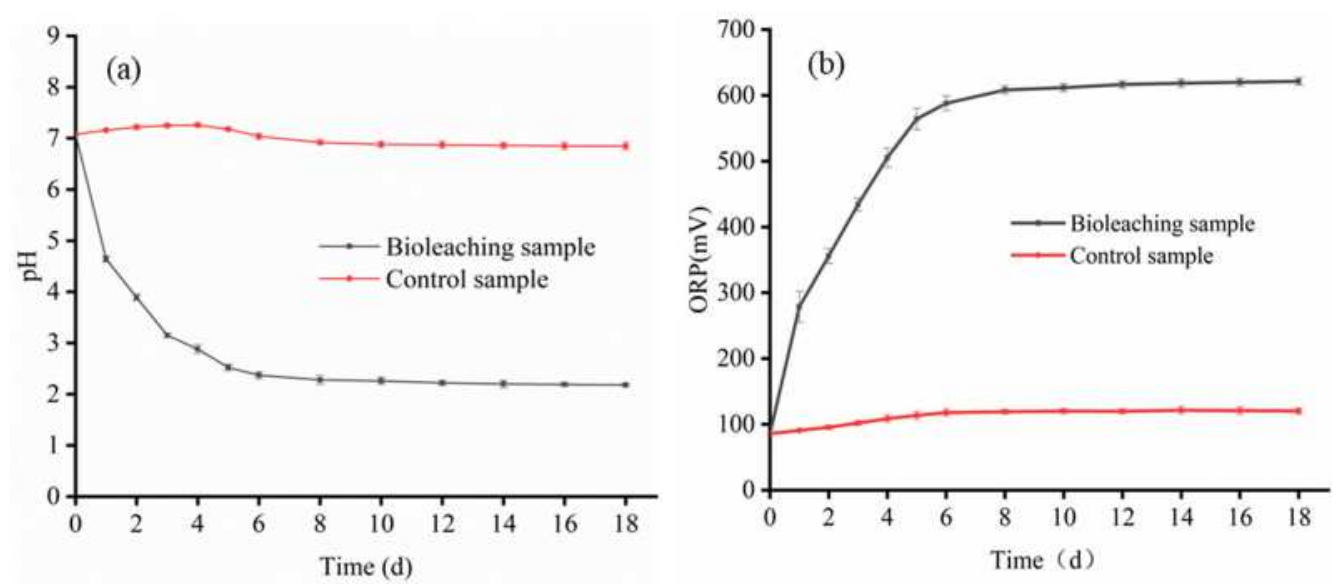

155

156

Fig. 2 Evolution of pH (a) and ORP (b) of control and bioleaching samples

\subsection{Heavy metals solubilization during bioleaching}

The dissolution of heavy metals in the bioleaching is shown in Fig. 3. The leaching amount of $\mathrm{Zn}$ from the sludge increased sharply. After $4 \mathrm{~d}$, the $\mathrm{Zn}$ removal reached a high of $71.4 \%$, and then increased slowly and stabilized at $83.8 \%$. In the initial stage, the $\mathrm{pH}$ of the sludge decreased greatly, leading to a sharp increase in the leaching of $\mathrm{Zn}$, which indicated that the leaching of $\mathrm{Zn}$ was closely related to the change in $\mathrm{pH}$ (Chan et al. 2003). At the same time, $\mathrm{Zn}$ was the most unstable metal, and 
$72.7 \%$ of the metal concentration existed in the unstable form, verifying that when the environment changed, $\mathrm{Zn}$ easily migrated. The dissolution effect of $\mathrm{Cu}$ was different from that of $\mathrm{Zn}$. The dissolution rate of $\mathrm{Cu}$ was only $6.6 \%$ after $2 \mathrm{~d}, 60.3 \%$ after $6 \mathrm{~d}$, and slowly increased to $70 \%$ after $18 \mathrm{~d}$. Only when the ORP was greater than $250 \mathrm{mV}$ did $\mathrm{Cu}$ begin to leach, which is consistent with previous studies (Pathak et al. 2009). Approximately $80 \%$ of Pb existed in a stable form. Slow leaching began after $2 \mathrm{~d}$ of bioleaching, and the leaching rate was only $19.4 \%$ after $6 \mathrm{~d}$. $\mathrm{Pb}$ was not efficiently solubilized from the sludge due to the formation of poorly soluble PbSO4 (Chen \&Chou 2016). The dissolution effect of $\mathrm{Mn}$ and $\mathrm{Zn}$ was similar, and the removal effect reached a higher level after $6 \mathrm{~d}$. The results showed that the removal efficiency of $\mathrm{Cu}, \mathrm{Zn}, \mathrm{Mn}$ and $\mathrm{Pb}$ reached a high level at 8, 6, 6 and $8 \mathrm{~d}$, respectively. As the bioleaching time continued to increase, the heavy metal removal rate slowly increased, indicating that continued bioleaching had little effect on the removal of heavy metals.

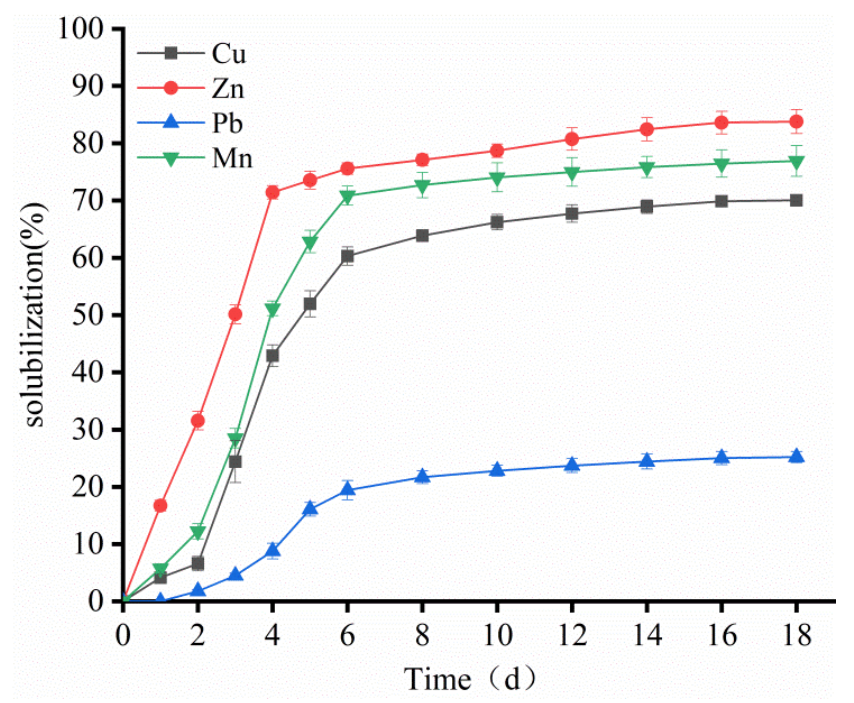

Fig. 3 Solubilization of heavy metals during the bioleaching treatment

\subsection{Removal of heavy metals by bioleaching combined with PDS}

The influence of different concentrations of $\mathrm{K}_{2} \mathrm{~S}_{2} \mathrm{O}_{8}$ on the dissolution of heavy metals is displayed in Fig. 4. The dissolution of heavy metals further increases with increasing of $\mathrm{K}_{2} \mathrm{~S}_{2} \mathrm{O}_{8}$ concentration. One reason was that under acidic conditions, PDS can form $\mathrm{SO}_{4}^{-}(\mathrm{E} 0=2.5-3.1 \mathrm{~V})$ through proton catalysis. Due to its high redox potential, most organic pollutants, including heavy metals, can be oxidized as shown in Eqs.(1) and (2) (Buxton et al. 1999). The formed $\mathrm{SO}_{4}{ }^{-}$can react with water to form $\cdot \mathrm{OH}$, which has a high redox potential $(\mathrm{E} 0=2.8 \mathrm{~V})$ and can oxidize heavy metals in sludge together with $\cdot \mathrm{SO}_{4}^{-}$according to Eq. (3).

$$
\mathrm{S}_{2} \mathrm{O}_{8}^{2-}+\mathrm{H}^{+} \rightarrow \mathrm{HS}_{2} \mathrm{O}_{8}^{-}
$$




$$
\mathrm{S}_{2} \mathrm{O}_{8}^{2-}+\mathrm{e}^{-} \rightarrow \cdot \mathrm{SO}_{4}^{-}+\mathrm{SO}_{4}^{2-}+\mathrm{H}^{+}
$$

$$
\cdot \mathrm{SO}_{4}^{-}+\mathrm{H}_{2} \mathrm{O} \rightarrow \mathrm{SO}_{4}^{2-}+\cdot \mathrm{OH}+\mathrm{H}^{+}
$$

The other reason was that many researchers found that under normal temperature neutral conditions, PDS oxidation capacity is limited and the reaction speed is slow; after heat (Xiong et al. 2018), ultraviolet (Wang \&Liang 2014), microwave ???, transition metal (Gao et al. 2018) activation can quickly generate $\cdot \mathrm{SO}_{4}^{-}$. Among them, $\mathrm{Fe}^{2+}$ is the most commonly used transition metal (Shi et al. 2015b). Therefore, an experiment combining bioleaching and PDS was designed to remove heavy metals from metallurgical industry sludge. In the novel combined treatment, on the one hand after $6 \mathrm{~d}$ of bioleaching, the $\mathrm{pH}$ drops below 2.5, and the acidic environment can accelerate the conversion of PDS to $\cdot \mathrm{SO}_{4}^{-}$. On the other hand, iron oxidizing bacteria involved in bioleaching can generate $\mathrm{Fe}^{2+}$, which acts as a catalyst, further promoting $\mathrm{PDS}$ generation $\cdot \mathrm{SO}_{4}^{-}$. Due to the high $\mathrm{ORP}$ of $\cdot \mathrm{SO}_{4}^{-}$, it can oxidize most of the organic matter in the sludge, and can destroy the extracellular polymers (EPS) of the sludge and lyse the bacterial cells (Liu et al. 2016), thus leading to the release of heavy metals in the sludge.

When the does exceeded $8 \mathrm{~g} / \mathrm{L}$, the dissolution of heavy metals did not increase significantly, and even showed a decreasing trend. The reason is that excess PDS may react directly with the generated $\cdot \mathrm{SO}_{4}^{-}$to produce less oxidizing $\mathrm{SO}_{4}^{2-}$ (Eq.(4)) (Liu et al. 2018; Oh et al. 2009). Even the reaction between the radicals themselves may occur based on Eq. (5) (Brandt \&Vaneldik 1995).

$$
\begin{aligned}
& \cdot \mathrm{SO}_{4}^{-}+\mathrm{S}_{2} \mathrm{O}_{8}^{2-} \rightarrow \mathrm{S}_{2} \mathrm{O}_{8}^{2-}+\mathrm{SO}_{4}^{2-} \\
& \cdot \mathrm{SO}_{4}^{-}+\cdot \mathrm{SO}_{4}^{-} \rightarrow \mathrm{S}_{2} \mathrm{O}_{8}^{2-}
\end{aligned}
$$

When the optimal dosage of potassium PDS was $8 \mathrm{~g} / \mathrm{L}$, the removal of $\mathrm{Cu}, \mathrm{Zn}, \mathrm{Pb}$ and $\mathrm{Mn}$ increased by $14.8 \%, 8.7 \%, 17.3 \%$, and $10.7 \%$, respectively, compared with that without potassium PDS. The addition of $\mathrm{K}_{2} \mathrm{~S}_{2} \mathrm{O}_{8}$ has a higher effect on $\mathrm{Cu}$ and $\mathrm{Pb}$ than on $\mathrm{Zn}$ and $\mathrm{Mn}$. As shown in Fig. 1, $60.0 \%$ and $29.8 \%$ of $\mathrm{Cu}$ and $\mathrm{Pb}$ in the original sludge respectively exist in the form of $\mathrm{B} 3$. The heavy metals existing in B3 were more closely combined with organic matter. The addition of potassium PDS can destroy the organic matter in the sludge and the EPS adsorbing heavy metals. The oxidation of EPS releases metal sulfide, which further increases the dissolution rate of heavy metals. The reasons for the low effect on $\mathrm{Zn}$ and $\mathrm{Mn}$ were as follows: On the one hand, the removal of $\mathrm{Zn}$ and $\mathrm{Mn}$ by $6 \mathrm{~d}$ bioleaching was already very high, and there was little room for further improvement. As shown in Fig. 1, only $15.2 \%$ and $8.6 \%$ of $\mathrm{Zn}$ and Mn existed in the form of B3 respectively, and the combination with 

metals.

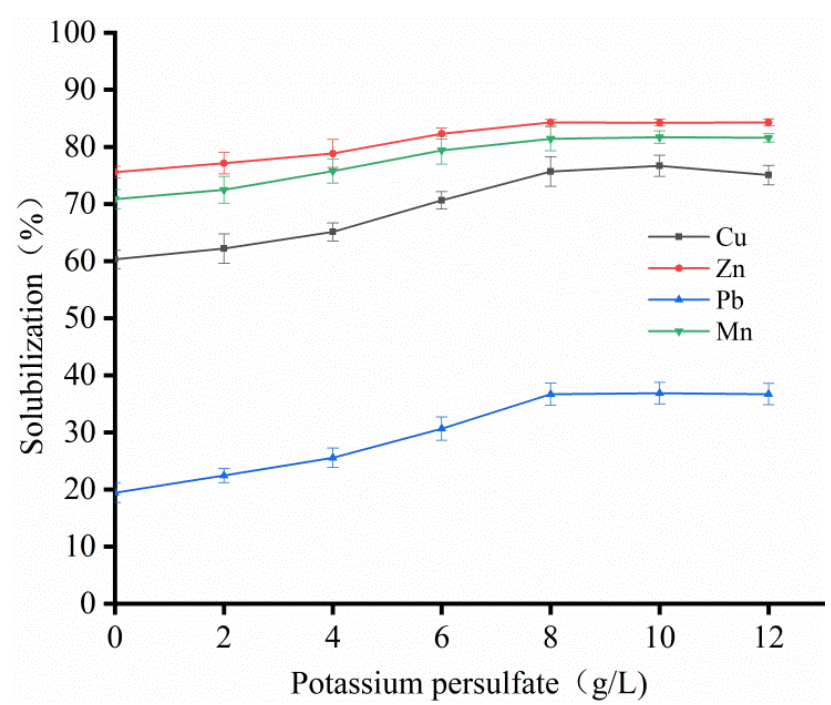

Fig .4 Effect of potassium persulfate dosage on heavy metal solubilization

\subsection{Variation in chemical form of heavy metals}

The removal rate of heavy metals in sludge was the focus of research, while the speciation of heavy metals was also a research topic that cannot be investigated. The chemical form of heavy metals has an inseparable relationship with the migration and biological toxicity of heavy metals (Renoux et al. 2001). Fig. 5 shows the chemical speciation composition of various heavy metals in the original sludge, and bioleaching combined with PDS treatment. The removal of $\mathrm{Cu}$ bioleaching for $18 \mathrm{~d}$ reached $70.0 \%$, as displayed in Fig. 3. The calculated removal of $\mathrm{Cu}$ in $\mathrm{B} 3$ was $82.8 \%$, while the combined treatment could further improve the removal of $\mathrm{B} 3$ to $88.3 \%$, according to Fig. 5a, which may be due to the further oxidation of sulfate radicals leading to an the increase in the B3 removal rate. Meanwhile, the removal rates of acid extractable B1 and reducible B2 also increased, as shown in Fig. 5a. The form of $\mathrm{Cu}$ mainly existed in B4 after the combined treatment, accounting for $60 \%$ of the total amount, which could reduce the migration of $\mathrm{Cu}$. Hence, the stability of $\mathrm{Cu}$ was strengthened and the harm to the environment was reduced.

Compared with the original sludge, $72.7 \%$ of $\mathrm{Zn}$ was dissolved after bioleaching, as displayed in Fig. 3. As shown Fig. 5b, the removed $\mathrm{Zn}$ was mainly based on the forms of B1 and B2. However, the most stable B4 decreased, which was probably due to acidification and biological oxidation. In the combined treatment, the removal rate of B4 was significantly lower than that of bioleaching alone, so the removal of B4 mainly occurred after $6 \mathrm{~d}$ of bioleaching, which was consistent with the results of 
existing studies (Zeng et al. 2015).

According to Fig. 5c, Pb mainly existed in the form of B4 and B3, 48.3\% and 29.8\%, respectively, and only $7.3 \%$ and $14.6 \%$ existed in the form of $\mathrm{B} 1$ and $\mathrm{B} 2 . \mathrm{Pb}$ in the $\mathrm{B} 1$ and $\mathrm{B} 2$ forms was mainly removed by bioleaching, while the removal effect of $\mathrm{Pb}$ in the $\mathrm{B} 3$ and $\mathrm{B} 4$ forms was slightly affected by bioleaching. However, due to the strong oxidation of sulfate radicals, $64.7 \%$ of $\mathrm{Pb}$ in the form of $\mathrm{B} 3$ was removed during the combination treatment. After the combination treatment, $87.4 \%$ of $\mathrm{Pb}$ existed in a stable state (B3 and B4), and its migration was reduced.

From Fig. 5d, it can be seen that the form of Mn was similar to that of $\mathrm{Zn}$, mainly in the form of B1 and B2. The acidic environment produced by bioleaching could be conducive to the removal of all the forms of Mn in the sludge. The combined treatment could further strengthen the removal of each form of Mn. It mainly existed in the form of B3 and B4 after combined treatment and became more stable.
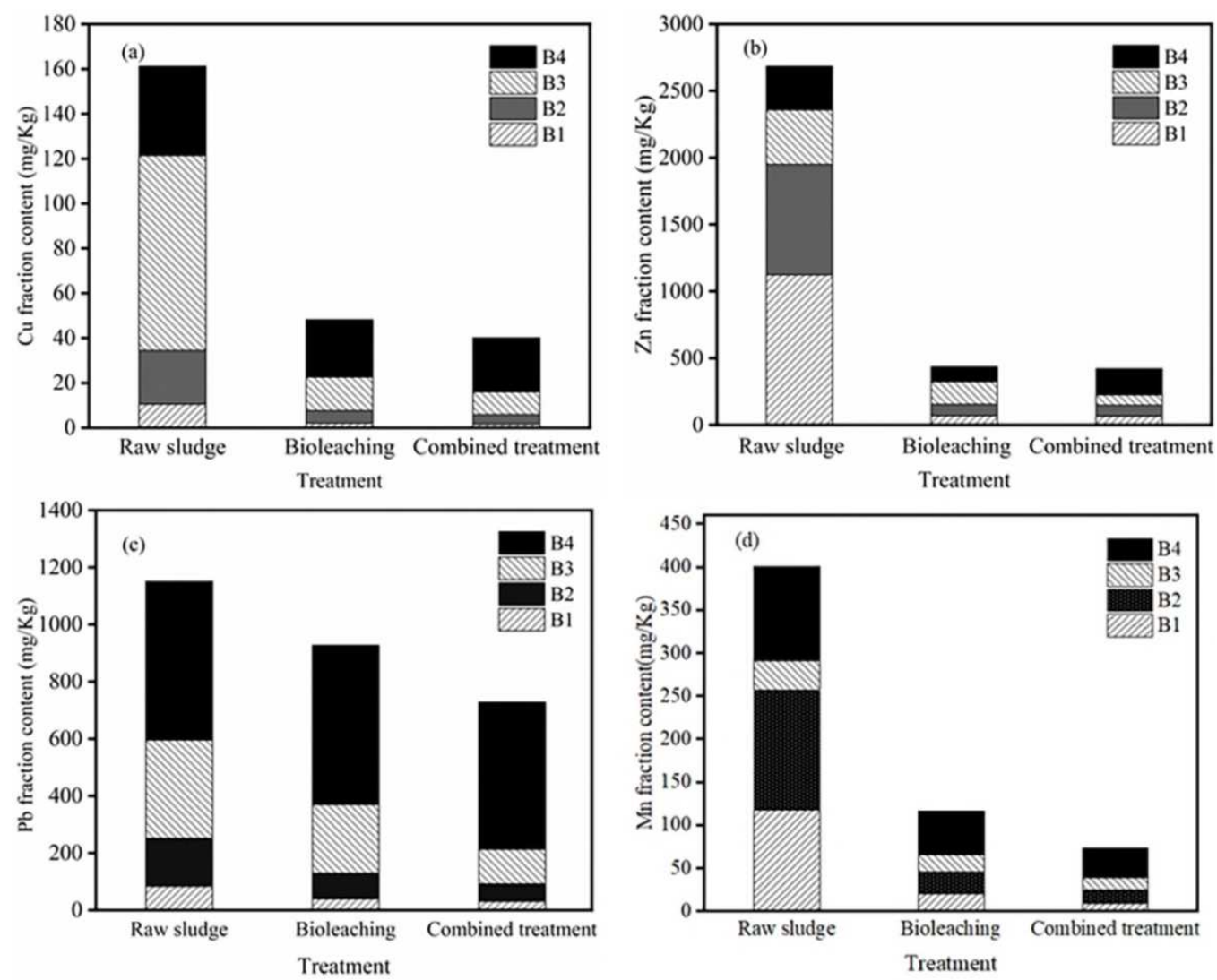

Fig .5 Effect of bioleaching and combined treatment on contents and chemical fractionation of heavy metals

\subsection{Structural analysis}


Fig. 6 shows the FT-IR spectra of the original sludge, the control group ,bioleaching treated residue and combined treatment residue at wavelengths of 4000-400 cm-1. The broad absorption peak at $3404 \mathrm{~cm}-1$ can be attributed to the hydroxyl groups of the hydrated oxide surface and the adsorbed water (Mahmoud 2014).

In the original sludge (Fig. 8a), $\mathrm{SO}_{4}^{2-}$ groups were attached at bands of $1157 \mathrm{~cm}-1$ and $652 \mathrm{~cm}-1$, probably because most metals in the sludge existed in the form of hydroxides, oxides, or sulfates (Wang et al. 2018). Because the control group was not inoculated with microorganisms and energy substances, there was no significant change in the control group. The peaks at $505 \mathrm{~cm}-1$ can be attributed to the stretching vibration of $\mathrm{M}-\mathrm{O}$ (where $\mathrm{M}$ corresponds to $\mathrm{Cu}, \mathrm{Zn}, \mathrm{Pb}$ and $\mathrm{Mn}$ ) (Horeh et al. 2016). Through comparison, it was found that the strength in the leaching residue was significantly reduced, which indicates that heavy metals in the sludge were removed. The peak at $1632 \mathrm{~cm}-1$ was associated with $\mathrm{C}=\mathrm{O}$, and $\mathrm{CO}_{3}^{2-}$ at $1446 \mathrm{~cm}-1$ (Horeh et al. 2016; Sun et al. 2021).

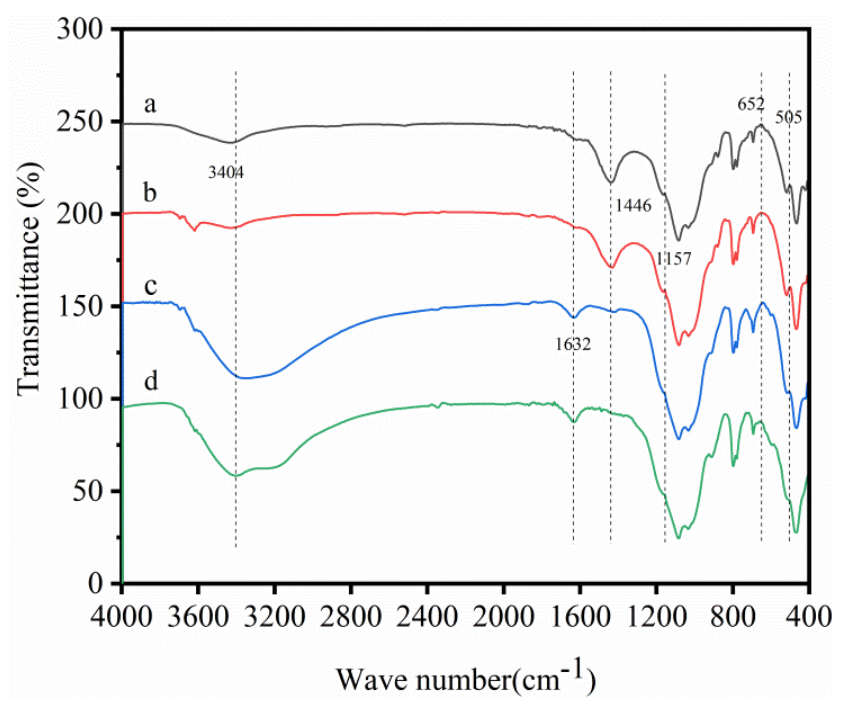

Fig. 6 FT-IR analysis of sludge before and after leaching in different groups. (a): raw sludge; (b): control group; (c): bioleaching group; (d): combined treatment group

\subsubsection{SEM analysis}

SEM was used to analyse the surface morphology of the original sludge and the treated residue. The result is shown in Fig. 7. The original sludge (Fig. 7a) was black and shiny, while the treated sludge (Fig. 7d) was yellow-brown. The micrographs showed significant differences in sludge morphology before and after treatment. The original sludge (Fig. $7 \mathrm{~b}$ and $7 \mathrm{c}$ ) has an irregular structure and the surface is almost smooth, while the treated doped sludge (Fig. 7e and 7f) has a rough and porous surface. This may be due to the action of microorganisms acidifying sludge, which causes the 
production of pores by the oxidation and reduction reaction of sludge (Rasoulnia et al. 2016).
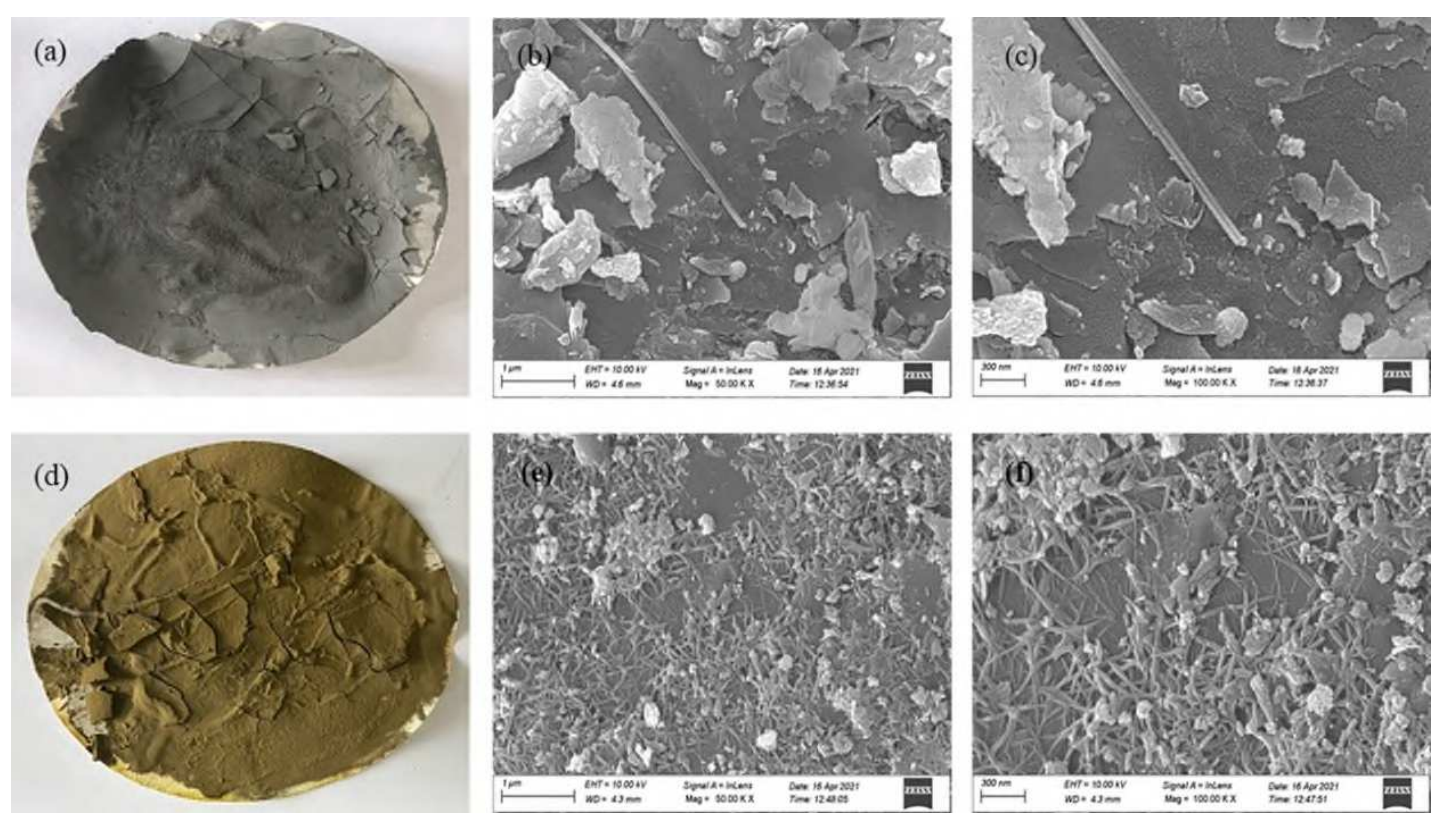

278 Fig. 7 The (a) camera image, (b) and (c) SEM image of raw sludge before bioleaching; (d) camera

279 image,(e) and (f) SEM image of sludge after combined treatment

\subsubsection{EDX analysis}

Fig. 8 and Fig. 9 show the EDX and mapping spectra of the original sludge and the treated residue.

The results showed that the metals were relatively concentrated distributed on the original sludge (Fig.

$2838 \mathrm{a}, \mathrm{c}, \mathrm{d}, \mathrm{e}$, and $\mathrm{f}$, dots with colour), and the metals were greatly reduced after the combined treatment

(Fig. 9a, c, d, e, and f). The EDX spectrum (Fig. 9b) of the treated metallurgical sludge showed that the contents of $\mathrm{Cu}$ and $\mathrm{Zn}$ were zero, indicating that the combined treatment had a high removal effect on

$\mathrm{Cu}$ and $\mathrm{Zn}$. The metal in the treated metallurgical sludge residue was mainly $\mathrm{Pb}$, which indicated that the combined treatment had an unsatisfactory effect on the removal of $\mathrm{Pb}$. This was consistent with the remove heavy metals from metallurgical sludge. 

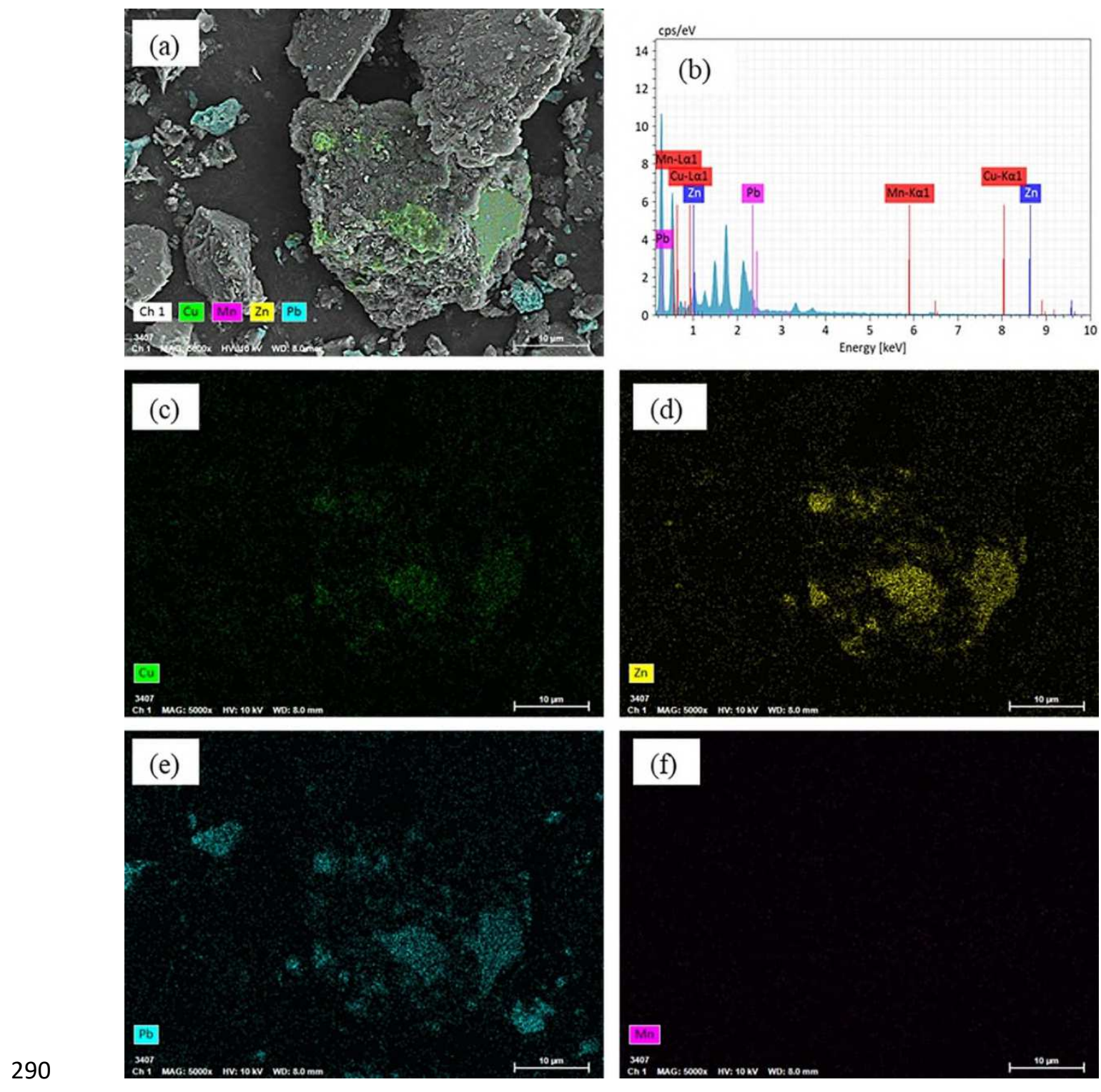

Fig. 8 EDX and elemental mapping analysis of the raw sludge (a, b, c, d, e and f ) 

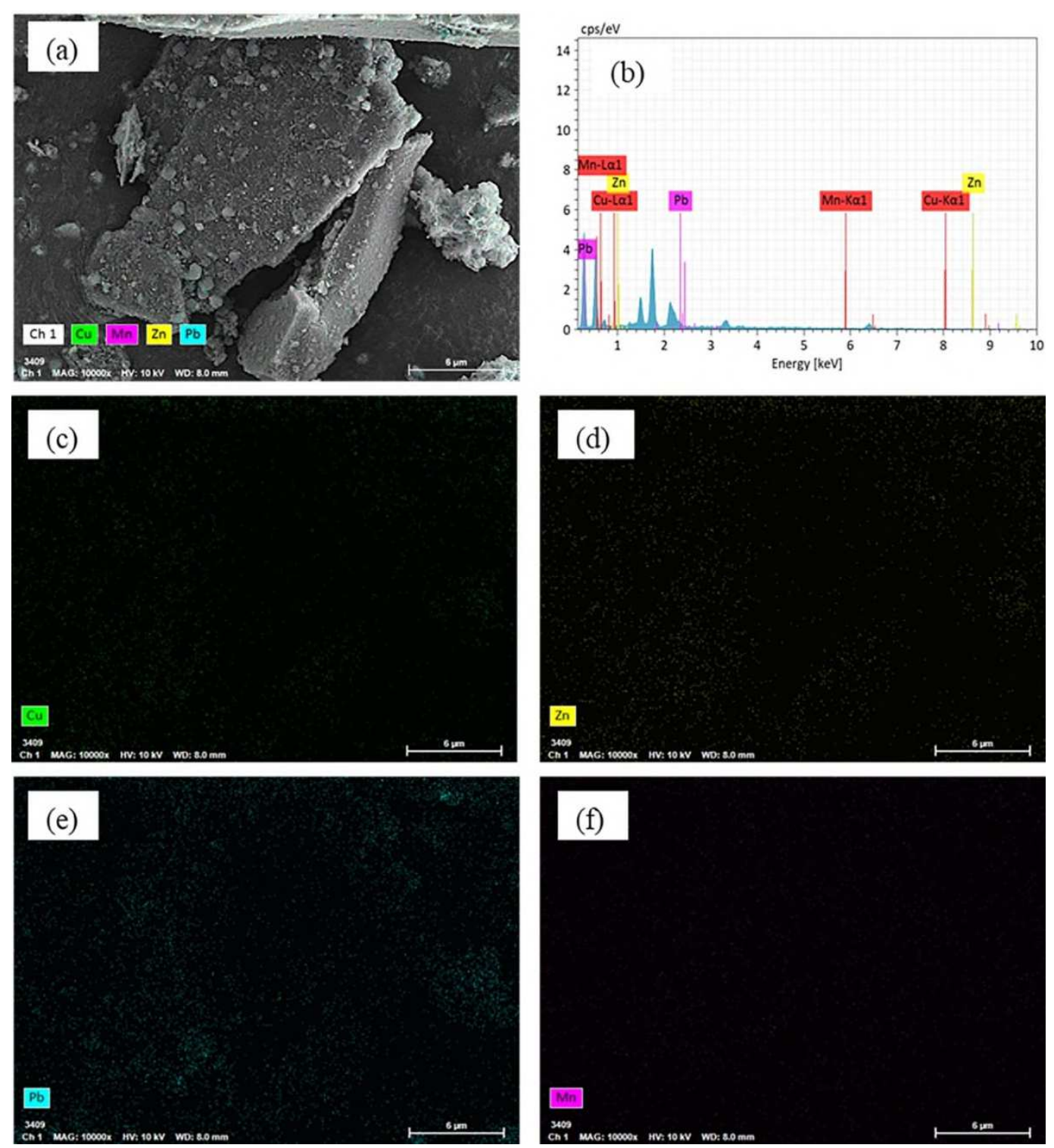

293 Fig. 9 EDX and elemental mapping analysis of the the combined treatment residue (a, b, c, d, e and f)

\section{Conclusions}

In this research, the iron-oxidizing bacteria isolated from sludge were be used as experimental strains for bioleaching and achieved satisfying effects of sludge acidification. After $18 \mathrm{~d}$ of bioleaching alone, the removal of $\mathrm{Cu}, \mathrm{Zn}, \mathrm{Pb}$, and $\mathrm{Mn}$ reached $70 \%, 83.8 \%, 25.2 \%$ and $76.9 \%$, respectively. Meanwhile, the heavy metals mainly existed in the forms of B3 and B4, resulting in reduced mobility. The concentration of PDS significantly affected the removal of heavy metals. When bioleaching was carried out for $6 \mathrm{~d}$, the $\mathrm{pH}$ reached an optimal value. The optimal $\mathrm{K}_{2} \mathrm{~S}_{2} \mathrm{O}_{8}$ dosage was $8 \mathrm{~g} / \mathrm{L}$, and after 1 $\mathrm{h}$ of reaction, the removal of $\mathrm{Cu}, \mathrm{Zn}, \mathrm{Pb}$, and $\mathrm{Mn}$ was $75.1,84.3,36.7$ and $81.6 \%$, respectively. Compared with bioleaching alone, the combined treatment has the following advantages: the treatment cycle was reduced from $18 \mathrm{~d}$ to $6 \mathrm{~d}+1 \mathrm{~h}$, the removal of heavy metals was increased, and the 

persulfate for the removal of heavy metals in metallurgical sludge and proves that combined treatment has the potential to remove heavy metals in sludge. 


\section{References}

Bayat B, Sari B (2010) Comparative evaluation of microbial and chemical leaching processes for heavy metal removal from dewatered metal plating sludge. J. Hazard. Mater. 174: 763-769. https://doi.org/10.1016/i.jhazmat.2009.09.117

Brandt C, Vaneldik R (1995) TRANSITION-METAL-CATALYZED OXIDATION OF SULFUR(IV) OXIDES ATMOSPHERIC-RELEVANT PROCESSES AND MECHANISMS. Chem. Rev. 95: 119-190. https://doi.org/10.1021/cr00033a006

Buxton GV, Bydder M, Salmon GA (1999) The reactivity of chlorine atoms in aqueous solution - Part II. The equilibrium SO4.-+Cl-reversible arrow Cl-.+SO42. PCCP Phys. Chem. Chem. Phys. 1: https://doi.org/269-273.10.1039/a807808d

Chan LC, Gu XY, Wong JWC (2003) Comparison of bioleaching of heavy metals from sewage sludge using iron- and sulfur-oxidizing bacteria. Advances in Environmental Research 7: 603-607. https://doi.org/10.1016/S1093-0191(02)00050-3

Chartier M, Couillard D (1997) Biological processes: The effects of initial pH, percentage inoculum and nutrient enrichment on the solubilization of sediment bound metals. Water, Air, Soil Pollut. 96: 249-267. https://doi.org/10.1007/BF02407208

Chen M, Li X-m, Yang Q, Zeng G-m, Zhang Y, Liao D-x, Liu J-j, Hu J-m, Guo L (2008) Total concentrations and speciation of heavy metals in municipal sludge from Changsha, Zhuzhou and Xiangtan in middle-south region of China. J. Hazard. Mater. 160: 324-329. https://doi.org/10.1016/j.jhazmat.2008.03.036

Chen S-Y, Chou L-C (2016) Relationship between microbial community dynamics and process performance during thermophilic sludge bioleaching. Environmental Science and Pollution Research 23: 16006-16014. https://doi.org/10.1007/s11356-016-6716-z

Deng X, Chai L, Yang Z, Tang C, Wang Y, Shi Y (2013) Bioleaching mechanism of heavy metals in the mixture of contaminated soil and slag by using indigenous Penicillium chrysogenum strain F1. J. Hazard. Mater. 248-249: 107-114. https://doi.org/10.1016/i.jhazmat.2012.12.051

Fontmorin JM, Sillanpää M (2015) Bioleaching and combined bioleaching/Fenton-like processes for the treatment of urban anaerobically digested sludge: Removal of heavy metals and improvement of the sludge dewaterability. Sep. Purif. Technol. 156: 655-664. https://doi.org/10.1016/i.seppur.2015.10.061

Fuentes A, Lloréns M, Sáez J, Aguilar MI, Ortuño JF, Meseguer VF (2004) Phytotoxicity and heavy metals speciation of stabilised sewage sludges. J. Hazard. Mater. 108: 161-169. https://doi.org/10.1016/i.jhazmat.2004.02.014

Gao F, Li Y, Xiang B (2018) Degradation of bisphenol A through transition metals activating persulfate process. Ecotoxicol. Environ. Saf. 158: 239-247. https://doi.org/10.1016/j.ecoenv.2018.03.035

Gunarathne V, Rajapaksha AU, Vithanage M, Adassooriya N, Cooray A, Liyanage S, Athapattu B, Rajakaruna N, Igalavithana AD, Hou D, Alessi DS, Ok YS (2019) Heavy metal dissolution mechanisms from electrical industrial sludge. Sci. Total Environ. 696: 133922. https://doi.org/10.1016/i.scitotenv.2019.133922

Guo J, Gao Q, Chen Y, He Q, Zhou H, Liu J, Zou C, Chen W (2021) Insight into sludge dewatering by advanced oxidation using persulfate as oxidant and Fe2+ as activator: Performance, mechanism and extracellular polymers and heavy metals behaviors. J. Environ. Manag. 288: 112476. https://doi.org/10.1016/i.jenvman.2021.112476

Horeh NB, Mousavi SM, Shojaosadati SA (2016) Bioleaching of valuable metals from spent lithium-ion 
mobile phone batteries using Aspergillus niger. J. Power Sources 320: 257-266. https://doi.org/10.1016/i.jpowsour.2016.04.104

Huang Z, Liu C, Zhu X, Xiang G, Zeng C, Zhong Y (2019) Behaviors of dewaterability and heavy metals of waste activated sludge conditioned by heat-activated peroxymonosulfate oxidation. Chem. Pap. 74: 641-650. https://doi.org/10.1007/s11696-019-00912-9

Li Y, Yang F, Miao S, Wang D, Li Z, Yuan X, Yuan L, Liu Q (2021) Achieved deep-dewatering of dredged sediments by $\mathrm{Fe}(\mathrm{II})$ activating persulfate pretreatment: Filtrating performance and mechanistic insights. Chem. Eng. J. 405: 126847. https://doi.org/10.1016/i.cej.2020.126847

Liu C, Wu B, Chen Xe (2018) Sulfate radical-based oxidation for sludge treatment: A review. Chem. Eng. J. 335: 865-875. https://doi.org/10.1016/i.cej.2017.10.162

Liu H, Liu Y, Tang L, Wang J, Yu J, Zhang H, Yu M, Zou J, Xie Q (2020a) Egg shell biochar-based green catalysts for the removal of organic pollutants by activating persulfate. Sci. Total Environ. 745: 141095. https://doi.org/10.1016/i.scitotenv.2020.141095

Liu J, Yang Q, Wang D, Li X, Zhong Y, Li X, Deng Y, Wang L, Yi K, Zeng G (2016) Enhanced dewaterability of waste activated sludge by Fe(II)-activated peroxymonosulfate oxidation. Bioresour. Technol. 206: 134-140.https://doi.org/10.1016/i.biortech.2016.01.088

Liu X, Wang J, Liu E, Yang T, Li R, Sun Y (2020b) Municipal sludge dewatering properties and heavy metal distribution: Effects of surfactant and hydrothermal treatment. Sci. Total Environ. 710: 136346. https://doi.org/10.1016/j.scitotenv.2019.136346

Liu Y-G, Zhou M, Zeng G-M, Wang X, Li X, Fan T, Xu W-H (2008) Bioleaching of heavy metals from mine tailings by indigenous sulfur-oxidizing bacteria: Effects of substrate concentration. Bioresour. Technol. 99: 4124-4129. https://doi.org/10.1016/i.biortech.2007.08.064

Lu Y, Zheng G, Zhou W, Wang J, Zhou L (2019) Bioleaching conditioning increased the bioavailability of polycyclic aromatic hydrocarbons to promote their removal during co-composting of industrial and municipal sewage sludges. Sci. Total Environ. 665: 1073-1082. https://doi.org/10.1016/i.scitotenv.2019.02.174

Mahmoud HR (2014) Highly dispersed Cr2O3-ZrO2 binary oxide nanomaterials as novel catalysts for ethanol conversion. J. Mol. Catal. A: Chem. 392: 216-222. https://doi.org/10.1016/j.molcata.2014.05.021

Mulligan CN, Yong RN, Gibbs BF (2001) Remediation technologies for metal-contaminated soils and groundwater: an evaluation. Eng. Geol. 60: 193-207. https://doi.org/10.1016/S0013-7952(00)00101-0

Naseri T, Bahaloo-Horeh N, Mousavi SM (2019) Bacterial leaching as a green approach for typical metals recovery from end-of-life coin cells batteries. J. Cleaner Prod. 220: 483-492. https://doi.org/10.1016/j.jclepro.2019.02.177

Nikfar S, Parsa A, Bahaloo-Horeh N, Mousavi SM (2020) Enhanced bioleaching of Cr and Ni from a chromium-rich electroplating sludge using the filtrated culture of Aspergillus niger. J. Cleaner Prod. 264: 121622. https://doi.org/10.1016/j.jclepro.2020.121622

Nzihou A, Stanmore B (2013) The fate of heavy metals during combustion and gasification of contaminated biomass-A brief review. J. Hazard. Mater. 256-257: 56-66. https://doi.org/10.1016/j.jhazmat.2013.02.050

Oh S-Y, Kim H-W, Park J-M, Park H-S, Yoon C (2009) Oxidation of polyvinyl alcohol by persulfate activated with heat, Fe2+, and zero-valent iron. J. Hazard. Mater. 168: 346-351. https://doi.org/10.1016/i.jhazmat.2009.02.065 
Pathak A, Dastidar MG, Sreekrishnan TR (2009) Bioleaching of heavy metals from sewage sludge by indigenous iron-oxidizing microorganisms using ammonium ferrous sulfate and ferrous sulfate as energy sources: A comparative study. J. Hazard. Mater. 171: 273-278. https://doi.org/10.1016/i.jhazmat.2009.05.139

Quevauviller P, Rauret G, López-Sánchez JF, Rubio R, Ure A, Muntau H (1997) Certification of trace metal extractable contents in a sediment reference material (CRM 601) following a three-step sequential extraction procedure. Science of The Total Environment 205: 223-234. https://doi.org/10.1016/S0048-9697(97)00205-2

Rasoulnia P, Mousavi SM, Rastegar SO, Azargoshasb H (2016) Fungal leaching of valuable metals from a power plant residual ash using Penicillium simplicissimum: Evaluation of thermal pretreatment and different bioleaching methods. Waste Manag. 52: 309-317. https://doi.org/10.1016/i.wasman.2016.04.004

Renoux AY, Tyagi RD, Samson R (2001) Assessment of toxicity reduction after metal removal in bioleached sewage sludge. Water Res. 35: 1415-1424. https://doi.org/10.1016/S0043-1354(00)00400-0

Romdhana MH, Lecomte D, Ladevie B, Sablayrolles C (2009) Monitoring of pathogenic microorganisms contamination during heat drying process of sewage sludge. Process Saf. Environ. Prot. 87: 377-386. https://doi.org/10.1016/j.psep.2009.08.003

Shi C, Zhu N, Shang R, Kang N, Wu P (2015a) Simultaneous heavy metals removal and municipal sewage sludge dewaterability improvement in bioleaching processes by various inoculums. World Journal of Microbiology and Biotechnology 31: 1719-1728. https://doi.org/10.1007/s11274-015-1922-2

Shi Y, Yang J, Yu W, Zhang S, Liang S, Song J, Xu Q, Ye N, He S, Yang C, Hu J (2015b) Synergetic conditioning of sewage sludge via Fe2+/persulfate and skeleton builder: Effect on sludge characteristics and dewaterability. Chem. Eng. J. 270: 572-581. https://doi.org/10.1016/i.cej.2015.01.122

Sun J, Zhou W, Zhang L, Cheng H, Wang Y, Tang R, Zhou H (2021) Bioleaching of Copper-Containing Electroplating Sludge. J. Environ. Manag. 285: 11213. https://doi.org/10.1016/j.jenvman.2021.112133

Wang C-W, Liang C (2014) Oxidative degradation of TMAH solution with UV persulfate activation. Chem. Eng. J. 254: 472-478. https://doi.org/10.1016/i.cej.2014.05.116

Wang M, Gong X, Wang Z (2018) Sustainable electrochemical recovery of high-purity Cu powders from multi-metal acid solution by a centrifuge electrode. J. Cleaner Prod. 204: 41-49. https://doi.org/10.1016/i.jclepro.2018.09.020

Wen Y-M, Cheng Y, Tang C, Chen Z-L (2013) Bioleaching of heavy metals from sewage sludge using indigenous iron-oxidizing microorganisms. J. Soils Sediments 13: 166-175. https://doi.org/10.1007/s11368-012-0580-3

Xin B, Zhang D, Zhang X, Xia Y, Wu F, Chen S, Li L (2009) Bioleaching mechanism of Co and Li from spent lithium-ion battery by the mixed culture of acidophilic sulfur-oxidizing and iron-oxidizing bacteria. Bioresour. Technol. 100: 6163-6169. https://doi.org/10.1016/j.biortech.2009.06.086

Xiong Q, Zhou M, Liu M, Jiang S, Hou H (2018) The transformation behaviors of heavy metals and dewaterability of sewage sludge during the dual conditioning with $\mathrm{Fe}(2+)$-sodium persulfate oxidation and rice husk. Chemosphere 208: 93-100. 
Yang W, Song W, Li J, Zhang X (2020) Bioleaching of heavy metals from wastewater sludge with the aim

249:

126134. https://doi.org/10.1016/i.chemosphere.2020.126134

Yuan J, Zhang W, Xiao Z, Zhou X, Zeng Q (2020) +Efficient dewatering and heavy-metal removal in municipal sewage using oxidants. Chem. Eng. J. 388: 124298. https://doi.org/10.1016/i.cej.2020.124298

Zeng X, Twardowska I, Wei S, Sun L, Wang J, Zhu J, Cai J (2015) Removal of trace metals and improvement of dredged sediment dewaterability by bioleaching combined with Fenton-like reaction. J. Hazard. Mater. 288: 51-59. https://doi.org/10.1016/i.jhazmat.2015.02.017

Zhou J, Cheng H, Ma J, Peng M, Kong Y, Komarneni S (2021) Persulfate activation by MnCuS nanocomposites for degradation of organic pollutants. Sep. Purif. Technol. 261: 118290. 


\section{Ethics declarations}

454 Ethics approval and consent to participate

$455 \quad$ Not applicable.

456 Consent for publication

$457 \quad$ Not applicable.

458 Availability of data and materials

459 The data and materials used or analyzed during the current study are available from the

460 corresponding author on reasonable request.

\section{Competing interests}

462 The authors declare no competing interests.

\section{Acknowledgment}

464

465

This project was supported by the National Natural Science Foundation of China (42067031).

\section{Contributions}

466 Huidong Li: Conceptualization, Formal analysis, Writing - review \& editing, Funding acquisition.

Chen Chen: Methodology, Data curation, Formal analysis, Writing - original draft.

Fengjiao Cu: Investigation, Software.

470

Zhixia Wang, Xinxin Liu: Investigation, Visualization.

471

Gang Jiang, Tianjia Cheng: Data curation, validation.

Runying Bai, Lei Song: Supervision, Formal analysis. 